\title{
Legal family and infrastructure voids as drivers of regulated physical infrastructure firms' exposure to governmental discretion
}

\author{
Laura Fernández-Méndez \\ Universidad Pontificia Comillas, \\ ICAI-ICADE \\ Esteban García-Canal \\ Universidad de Oviedo \\ Mauro F. Guillén \\ The Wharton School, \\ University of Pennsylvania
}

Journal of International Management 21(2), pp. 135-149. 2015

\begin{abstract}
Firms operating in regulated physical infrastructure industries such as electricity, water or telecommunications do not always avoid the risks associated with governmental discretion when choosing a foreign country to invest in. We develop a theoretical framework based on the organizational capabilities view to account for the boundary conditions of this riskseeking behavior: countries with a similar legal system as the one of the home country and
\end{abstract}


with high infrastructure voids. An empirical analysis using panel data on the international expansion of Spanish listed firms from 1986 to 2008 confirmed our hypotheses.

Keywords: Governmental discretion; regulated physical infrastructure firms; location choice; legal system; political capabilities; infrastructure voids.

Acknowledgements: The authors thank to participants at the 2013 Strategic Management Society and ACEDE conferences. We thank the editor Massaiki Kotabe and three anonymous JIM reviewers for their insightful comments and guidance that helped shape the paper. We also thank Alfredo Jiménez Palmero for his suggestions. Financial support provided by the Spanish Ministry of Science and Innovation (Projects ECO2010-18718 and ECO2013-46235-R) is gratefully acknowledged. The first author also thanks the financial support received from the FPU program of the Ministry of Education in which she was enrolled prior to joining ICADE. 


\section{INTRODUCTION}

Recent research has shown that firms are heterogeneous in their attitudes toward governmental discretion (Alcantara and Mitsuhashi, 2012; García-Canal and Guillén, 2008; Henisz and Macher, 2004; Holburn and Zelner, 2010). By governmental discretion we mean the degree to which governments and regulators can unilaterally alter the conditions under which a firm carries out its activities in a country, i.e. "the rules of the game", potentially damaging the profitability of its investments (Henisz, 2000). The conventional wisdom states that firms should stay away from countries where governmental discretion is high to avoid being worse off due to unexpected changes in the rules of the game (Henisz, 2000; Henisz and Delios, 2001). Yet, recent evidence shows that not all firms avoid the exposure to governmental discretion. Most of this evidence comes from firms from regulated physical infrastructure industries (García-Canal and Guillén, 2008; Holburn and Zelner, 2010; Jiménez et al., 2014), although the evidence coming from these industries is not conclusive. For instance, Henisz (2002) and Henisz and Zelner (2001) found that governmental discretion deters investments in the telecommunications and electricity industries. Due to this mixed empirical evidence, more research is needed to identify the boundary conditions of this willingness to be exposed to governmental discretion by firms from regulated physical infrastructure industries. 
To fill this gap in the literature, in this paper we build a theoretical framework based on the organizational capabilities view (Amit and Schoemaker, 1993; Ethiraj et al., 2005; Madhok, 1997) aimed at explaining which factors increases the odds of a regulated physical infrastructure firm (RPIF) being exposed to governmental discretion. We argue that the willingness of RPIFs to invest in countries with governmental discretion increases in countries having both a legal system from the same family as the one of the home country and infrastructure voids. We consider regulated physical infrastructure industries to be those that were highly regulated in the past due to natural monopoly considerations (Bel and Fageda, 2013; Dorigoni and Portatadino, 2009; Ramamurti and Doh, 2004) and that, despite being affected by liberalization and deregulation processes around the world, entry for newcomers still requires acquiring a company owning one of the limited licenses available to operate in the industry or being awarded a new license or contract, usually through a competitive bid (Bonardi, 2004). We argue that, thanks to the political capabilities developed in the home country, these firms are less vulnerable to governmental discretion than firms from other industries. However, these capabilities are not equally fungible across countries. Our results show that countries with discretionary host governments, belonging to the same legal family as the one of the home country, and with high infrastructure voids provide the most suitable scenario for applying the RPIFs' accumulated political capabilities. In fact, we argue and provide evidence that when these two conditions are present in a country with governmental discretion, it is more likely that a RPIF will invest there than in a country without governmental discretion.

We test our hypotheses in a sample of Spanish listed companies that invested abroad during the 1986-2008 period. Companies from emerging countries are traditionally less 
deterred by underdeveloped institutions when they expand abroad (Cuervo-Cazurra and Genc, 2008, 2011). For this reason, using data from a country with stronger institutions, as Spain is, has the advantage of a more precise analysis of the attitudes to governmental discretion by firms from regulated physical infrastructure industries as compared to firms from the remaining industries. In addition, focusing in just one country allows us to control for the institutional environment in the home country.

\section{AN ORGANIZATIONAL CAPABALITIES VIEW OF THE RELATIONSHIP BETWEEN GOVERNMENTAL DISCRETION AND LOCATION CHOICE}

Foreign direct investment (FDI) is a process in which firms combine their firmspecific resources and capabilities developed at home (brands, technologies, know-how and so on) with local resources that facilitate the exploitation of the former in the host market and/or contribute to the overall development of the firm's resource set (Hennart, 2009; Madhok, 1997). Managing these transfers and combinations of resources and capabilities is a critical driver of success in the internationalization process. However, this is not an easy task, as the firm has to adapt to different idiosyncrasies specific to each country. For this reason, the ability to manage these idiosyncrasies is, per se, a firm-specific organizational capability that can generate rents (Henisz, 2003) or that can help firms extract rents from their other resources in adverse environments (Lawton and Rajwani, 2011; Oliver and Holzinger, 2008).

Governmental discretion is one of the most important institutional idiosyncrasies a firm must take into account when expanding abroad. When exposed to this discretion, the 
profitability of a firm's foreign investments can be damaged due to unexpected changes in taxation, pricing or the conditions for profit repatriation (Henisz and Williamson, 1999). Thus, avoiding countries with discretionary governments could be the natural behavior for most firms, irrespective of their industry, according to the results of previous research (Delios and Henisz, 2003; Duanmu 2012; Guler and Guillén, 2010; Henisz, 2002; Henisz and Delios, 2001; Henisz and Macher, 2004; Henisz and Zelner, 2001).

However, avoiding these countries is not the only option firms have when dealing with governmental discretion abroad. Companies have an alternative, i.e. managing this instability by using the knowledge and skills accumulated at home from their interaction with governments and regulators or, generally speaking, using their political capabilities. Political capabilities are part of the set of organizational capabilities of a firm. Consistent with the organizational capabilities branch of the resource-based view (RBV) (Amit and Schoemaker, 1993; Ethiraj et al., 2005; Madhok, 1997), we distinguish between political resources and political capabilities. Lawton et al. (2013) classify political resources at three levels: human (e.g. employees or directors with governmental or regulatory experience), structural (e.g. a specific unit for dealing with politicians and regulators) and network (e.g. social capital that can be mobilized by the organization). Political capabilities are the routines and organizational processes through which political resources are deployed to put in practice a firm's corporate political activities (Lawton et al., 2013).

Knowledge is one of the main building blocks of political capabilities. Holburn and Zelner (2010) argued that firms develop this sort of knowledge either through organizational learning or via cognitive imprinting processes. In the first case, firms learn from their own experience of dealing with governments and regulators (learning by doing). 
In the latter case, "as a result of shared experiences, home-country managers develop mental models—simplified representations of reality—which they then use to interpret the environment and guide their actions under conditions of uncertainty" (Holburn and Zelner, 2010: 1293).

Recent research shows that firms having political capabilities may use them to obtain favorable entry conditions in countries with discretionary governments (GarcíaCanal and Guillén, 2008; Holburn and Zelner, 2010; Jiménez, 2010), to obtain first mover advantages (Frynas et al., 2006) and/or to exercise lobbying activities (Lawton and Rajwani, 2011). All of these research efforts have contributed to the development of an organizational/political capabilities view of international expansion (Lawton et al., 2013) that offers a brand new perspective to analyzing the relationship between governmental discretion and FDI. The underlying hypothesis of this perspective is that firms accumulate expertise and capabilities related to dealing with governments and regulators in their home country that can be exploited and developed abroad.

Concurring with this organizational capabilities view, Cuervo-Cazurra and Genc (2008) showed that firms from developing countries are able to invest more in countries with underdeveloped institutions than firms from developed countries, as they are used to dealing with this instability at home. For the specific case of RPIFs, Henisz (2003) and Bonardi (2004) argued that these firms develop political capabilities because of their frequent interaction with politicians and regulators in their home country. García-Canal and Guillén (2008) documented for these firms a different investment pattern when facing governmental discretion in their international expansion than when facing macroeconomic uncertainty. They found that RPIFs in their sample avoided investing in countries where macroeconomic uncertainty was high, while they tended to enter into countries with high 
governmental discretion. Holburn and Zelner (2010) found that firms from the electric power-generation industry used to deal with discretionary governments were less afraid to invest in countries having this type of government. Taken as a whole, this evidence shows that political capabilities can be valuable advantages that could counteract the effect of governmental discretion, helping firms exploit their other capabilities in unfavorable environments.

\subsection{Hypotheses}

In this section, we analyze whether and why governmental discretion can attract or deter FDI for firms in regulated physical infrastructure industries, taking into account the moderating roles played by the home country legal family and the host country's level of infrastructure voids.

\section{Attitude toward governmental discretion across industries: RPIFs vs. other}

\section{companies}

As stated before, governmental discretion in the host country is a variable that, generally speaking, discourages FDI. However, some cross-industry variance can be expected. Industry conditions influence firms’ political behavior (Boddewyn and Brewer, 1994), and the extent of this behavior determines the accumulation of political capabilities. One of the main features of firms operating in regulated physical infrastructure industries is that they are more exposed to a government's decisions and policies (Bonardi, 2004; García-Canal and Guillén, 2008; Hillman, 2005), as parameters like the degree of 
competition, prices and investment requirements are conditioned by regulation (Hillman, 2005; Keim and Hillman, 2008; Mahon and Murray, 1981).This greater exposure pushes RPIFs to engage in a number of initiatives to influence governments' decisions (Dowling and Pfeffer, 1975). For instance, Hillman (2005) showed that these companies have more former politicians on their board of directors than other firms.

As organizational capabilities are the outcome of learning by doing (Amit and Schoemaker, 1993), accumulated experience in the home country led RPIFs to have not only more political resources, but also more organizational practices and routines to implement political strategies based on them. Consequently, these firms accumulate more experience and knowledge regarding the functioning of the political process, among other political capabilities, than the remaining firms (Bonardi, 2004).

When companies from regulated physical infrastructure industries decide to locate their investments in a foreign country, governmental discretion is a factor that increases their dependence on the regulator. However, when abroad, they can exploit the political skills developed at home to alleviate the negative impact of governmental discretion. Henisz (2003: 174) posited that "although the specific micro-level routines and practices necessary to manage idiosyncratic institutional environments will probably differ from country to country, firms may develop broader meta-level routines both to identify the idiosyncrasies in the institutional environment and to lobby or influence the actors who can best prevent an adverse policy change or promote a favorable policy change." In effect, even though some political resources, such as personal links to key actors in the home country, are country specific; political capabilities are fungible across countries. They also 
can be transferred to foreign subsidiaries, as happens with other organizational capabilities (Madhok, 1997).

Interestingly, political capabilities are more useful when dealing with discretionary governments, as these capabilities are especially applicable to deal with changing political environments (Oliver and Holzinger, 2008). The lack of checks and balances gives governments ample discretion to negotiate ad-hoc entry and operating conditions with foreign multinationals with political skills (García-Canal and Guillén, 2008). These entry conditions can entail reduced fees, less competition, privileged finance and so on. On the contrary, the existence of checks and balances make it more difficult to move beyond conventional practices in the industry, even after the implementation of political strategies (Holburn and Vanden Berg, 2002). In addition, FDI in regulated physical infrastructure industries is usually the consequence of privatization or liberalization programs, which are easier to put into practice by discretionary governments (García-Canal and Guillén, 2008).

Even though, governmental discretion, as previously mentioned, can be harmful to all kinds of firms, we expect that RPIFs will be less deterred by governmental discretion than the remaining ones. We expect the latter to be less equipped to deal with governmental discretion because they have fewer political capabilities. For this reason, they will prefer other destinations for their foreign investments. Considering all this, we formulate the following hypothesis:

Hypothesis 1. Governmental discretion deters RPIFs from entering a foreign country to a lesser extent than other types of firms. 


\section{The moderating role of the home country legal family}

Legal systems matter for RPIFs' location choice because they affect not only the way in which governmental agencies and regulatory bodies are organized, but also the level of regulation (La Porta et al., 2008). Legal origin scholars state that "countries have pervasive regulatory styles inherited from the transplantation of legal systems" (Botero et al., 2004: 1339). In fact, the literature on legal origins theory has established similarities between countries and their types of regulations depending on the origin of their legal systems. For instance, Botero et al. (2004) found that legal origins explain differences in labor regulations across 85 countries. Glaeser and Shleifer (2002) showed how the independence of the judicial system varies across legal families.

As organizational capabilities are context-specific (Ethiraj et al., 2005), we argue that the political capabilities developed by RPIFs in their home country are especially suited to the domestic legal family. This is because the knowledge and experience of dealing with politicians and regulators accumulated by a company in its home country are closely related to the legal institutions that define the country's legal family (Kothari et al., 2013). Obviously, specific laws vary across countries within the same family. However, some similarities exist inside each legal family regarding what is acceptable and what is not. In addition, when it comes to defending a firm's interests, each legal family has idiosyncratic ways of framing legal issues that firms must be aware of (Fainshmidt et al., 2014; La Porta et al., 2008; Luiz and Rupla, 2010; Scott, 2011). In the same vein, 
governments' behavior (e.g. the degree of interventionism) may be determined by the national law (La Porta et al. 1999; Macher and Mayo, 2014), making firms used to operate under the same legal family as the host country more able to anticipate the behavior of governments and policymakers. For all these reasons, the knowledge and skills accumulated by RPIFs in their home country are more fungible when expanding to countries from the same legal family.

At first sight, it could be expected that the political capabilities accumulated by firms from regulated physical infrastructure industries could be more effective in all countries from the same legal family. Not only in these countries national laws are close to that of their home country, but also governments' behavior is (La Porta et al., 1999; Macher and Mayo, 2014). Madhok (1997) argues that organizational capabilities can be both a source of competitive advantage and a constraint; as what firms can do is dependent on the fit between their capabilities and the context in which they are used. In this way, a firm's political capabilities are less fungible when the company is entering countries from a different legal family. In this scenario, the processes and routines the firm is used to apply may be either ineffective or not viable.

However, capitalizing abroad political capabilities do not only require host countries from the same legal family, but also governmental discretion. It is in countries with discretionary governments where RPIFs can leverage their political capabilities through corporate political activities, as we have argued previously. Nevertheless, when RPIFs expand into countries where governmental discretion is high and belonging to a different legal family, they have more difficulties in operating and dealing with regulations, because they lack the common ground provided by the similarity of the home and host national law 
systems. In other words, when RPIFs move outside the set of countries belonging to the same legal family, they are less able to alleviate the negative influence of governmental discretion. On the contrary, when approaching countries from the same legal family, they can leverage largely their political capabilities. These capabilities can be easily transferred and implemented in familiar contexts (Ethiraj et al., 2005; Madhok, 1997). Based on these arguments we state that:

Hypothesis 2. The deterring effect of governmental discretion on entering a foreign country by RPIFs is reduced when the home and host countries belong to the same legal family.

\section{The moderating role of the host country's level of infrastructure voids}

It could be expected that infrastructure voids will attract FDI by RPIFs. Host governments usually try to attract foreign investors to improve the provision of regulated services, hoping that the foreign investor will help to fill infrastructure voids (e.g. poorly developed telecommunications or electricity networks). In contrast, the absence of infrastructure voids brings another completely different scenario, as the foreign firm has less to offer to the host country. This fact is well documented in the literature on regulation theory, which shows that developed and developing countries have different objectives when they embark on privatization or deregulation processes (Boubakri et al., 2005; Parker and Kirkpatrick, 2005: 528). On the one hand, developed countries look for improvements in the provision of these services by fostering competition and raising extra funds through bidding processes. On the other hand, governments and regulators in developing countries 
are more concerned with the development of the infrastructure, something that is almost complete in developed countries, to promote economic development and national welfare.

Infrastructure voids in the host country are especially interesting for RPIFs investing abroad, mainly when they face governmental discretion. These voids make political capabilities a valuable tool in negotiating with discretionary host governments. Using their political capabilities RPIFs can get better entry conditions in exchange for their contribution in building the local infrastructure. At the same time, infrastructure voids also make host governments more willing to pave the way for the entry of foreign multinationals that could be of help to fill them. As previously mentioned, negotiations between RPIFs and host governments will be easier in countries with discretionary governments (GarcíaCanal and Guillén, 2008). In this situation, infrastructure voids encourage firms to undertake corporate political activities. In effect, by leveraging their political capabilities, they can take advantage of their higher bargaining power due to infrastructure voids, increasing their chances to obtain better outcomes in their negotiations. Thus, we argue that:

Hypothesis 3. The deterring effect of governmental discretion on entering a foreign country by RPIFs is reduced when the host country infrastructure voids are high.

The joint moderating role of the home country's legal family and the host country's level of infrastructure voids

In isolation, a similar legal system and the existence of infrastructure voids may be not enough for RPIFs to fully leverage their political capabilities when dealing with 
discretionary governments. On the one hand, political capabilities cannot be effective enough to take advantage of infrastructure voids if they do not fit with local institutional conditions. A match between the host country environment and organizational capabilities is always advisable (Madhok, 1997; Oliver and Holzinger, 2008; Teece et al., 1997). On the other hand, entering countries from the same legal family but without infrastructure voids can leave the company without bargaining chips as local infrastructure is already completed, making more difficult to profit from political capabilities. Therefore, it is in countries belonging to the same legal family as the one of the home country and high infrastructure voids where the political capabilities accumulated by a RIF can be better exploited in the bargaining processes with discretionary host governments. In this specific context, governmental discretion in the host country becomes a positive force in attracting RPIFs investments. In any other situation in which one of these two conditions does not apply, governmental discretion will discourage entry by RPIFs. Specifically, as infrastructure voids are filled, the value of the foreign multinational political capabilities approaching a country where the government enjoys ample discretion also sharply decreases, as this company has less to offer to the host country. In this case, new contributions to local infrastructure are not required, perhaps because a foreign firm has already invested in this country and obtained favorable conditions. This is why RPIFs are expected to increase their propensity to enter into countries with discretionary governments from the same legal family while the infrastructure voids are high. Based on these arguments, we state in our fourth hypothesis that: 
Hypothesis 4. The effect of governmental discretion on entering a foreign country by RPIFs turns positive when both the home and host countries belong to the same legal family, and the host country infrastructure voids are high.

\section{SAMPLE, VARIABLES AND METHOD}

\subsection{Sample}

Our sample comprises the FDI location choices made from 1986 to 2008 by the whole set of Spanish firms listed on the Madrid Stock Exchange in 1990. Even though there used to be several stock exchanges in Spain (i.e. Madrid, Barcelona, Valencia and Bilbao, now integrated in Bolsas y Mercados Españoles), the most important is Bolsa de Madrid. For this reason, we focused only on firms listed on the Madrid Stock Exchange. The main reason for using data from Spanish firms lies in the fact that the internationalization of these companies is a recent phenomenon (Guillén, 2005), meaning that we can include the bulk of their FDI in our database. In fact, the initial year of our sample is especially appropriate because it was the year of the effective entry of Spain into the European Economic Community (nowadays European Union). From this moment, Spanish companies started to invest significantly abroad. According to UNCTAD data, the stock of FDI was only $0.85 \%$ of GDP in 1980 , but increased to $2.43 \%$ in 1986 , to $10.27 \%$ in 1998 and to $42.46 \%$ in 2011.

The sample comprises 105 firms from regulated physical infrastructure and other industries. As previously mentioned, we consider as regulated physical infrastructure those 
that were highly regulated in the past due to natural monopoly considerations (Bel and Fageda, 2013; Dorigoni and Portatadino, 2009; Ramamurti and Doh, 2004) and that, despite being affected by liberalization and deregulation processes around the world, entry for newcomers still requires acquiring a company owning one of the limited licenses available to operate in the industry or being awarded a new license or contract, usually through a competitive bid (Bonardi, 2004). Most studies analyzing RPIFs include energy industries (electricity, gas and petrol), as well as water, telecommunications, and construction in the core of infrastructure firms (Guthrie, 2006; Kirkpatrick et al., 2006; Parker, 2003; Ramamurti and Doh, 2004). The construction industry is included in this group of industries because a great part of these companies' activities is to develop statefunded large infrastructure projects. Usually, these firms not only build infrastructure assets, but also operate them after successfully bidding for a license or a PPP (publicprivate partnership) agreement, which also entails extensive monitoring by the government (Grimsey and Lewis, 2007: 2). Therefore, following previous works, we considered as regulated physical infrastructures the telecommunications, water, construction, and energy (electricity, gas and petroleum) industries. However, for the sake of comparing our results with previous research, we also ran additional tests considering as regulated other industries such as the banking industry, as explained later.

Data on the number of entries were obtained from the Systematic Database on the International Operations of Spanish Companies, built under the sponsorship of the Spanish Institute for Foreign Trade, ICEX (see Guillén and García-Canal, 2007). This database comprises international operations carried out by Spanish firms in the 1986-2008 period. The database categorizes several types of international operations: strategic alliances 
(distribution agreements, research and development projects, technological alliances); jointventures; partial and total acquisitions; administrative concessions; and greenfield wholly owned subsidiaries. For this study, we included only FDI, which generates a higher level of sunk costs in the process of entering a foreign country. We consider as FDIs those operations in which the firm possesses $10 \%$ or more of a foreign company (U.S. Bureau of Economic Analysis, 2004). Therefore, operations such as technical assistance, licensing agreements or similar were excluded, since they do not constitute an investment in the traditional sense of the term.

\subsection{Variables}

Our dependent variable is a count variable defined as the number of entries in each unique firm-country-year combination. Our unit of observation is thus firm-country-year.

The independent variable of the model is governmental discretion, defined as the degree to which governments can unilaterally alter the conditions in which firms operate in a country, in a way that affects investments' profitability (Henisz, 2000). This definition of governmental discretion refers to the existence of checks and balances in the host country. To measure it, we used the political constraint (POLCONV) index developed by Henisz (2000). This index turns out to be the most accurate and widely used measurement from which we can build a governmental discretion index (Berry, 2013; Fuentelsaz et al., 2014; García-Canal and Guillén, 2008; Henisz and Delios, 2001; Holburn and Zelner, 2010; Perkins, 2014; Zelner et al., 2009). The POLCONV index accounts on a yearly basis for the number of independent power branches-e.g. the executive, legislative and judicial 
powers-with veto capacity over policy changes in each country as well as the degree of alignment among them. Scores in this index range from zero to one, zero being the minimum level of political constraint and one the highest. The higher the POLCONV index is (i.e. the higher the number of power branches with veto capacity and the lower the alignment among them), the more difficult it is for politicians to unilaterally change the rules of the game. As other authors have done before, from the POLCONV index we built a governmental discretion index as follows: Governmental discretion=1-POLCONV (Fuentelsaz et al., 2014; Guillén and García-Canal, 2008; Holburn and Zelner, 2010). This governmental discretion index ranges from zero to one, zero being the lowest governmental discretion level and one being the highest.

Our moderating variables are the similarity between the home and host country national laws and the level of the host country's infrastructure voids. To measure the first variable, we built a dummy variable ("Civil code"), valued at one if the host country legal family is the civil code, which is the system used in Spain, and valued at zero otherwise. Countries that have a hybrid legal system were coded as zeroes. To build this variable, we used La Porta et al.'s (2008) data. To measure the host country's infrastructure voids, we created an index ranging from zero to one, zero being the lowest level of infrastructure voids and one the highest. Specifically, we first developed an index of infrastructure development and then we reversed it to have an index of infrastructure voids. To do this, we gathered different variables from the World Bank Database Indicators to serve as proxies of the degree of the development of the local infrastructure for each regulated infrastructure industry. We used the following indicators to develop this index: the percentage of the population with access to water for firms in the water industry; the 
complete road network ${ }^{1}$ ( $\mathrm{km}$ of roads per capita) for firms in the construction industry; electricity production ( $\mathrm{kWh}$ produced per capita) for firms in the electricity industry; number of mobile cellular subscriptions per capita for firms in the telecommunication industry; and use of primary energy (measure as $\mathrm{kg}$ of oil per capita) for firms in the energy industry. Finally, we divided each value between the maximum value of the analyzed period (1986-2008) taking into account all potential host countries (by industry) to obtain an index that ranges from zero to one and was comparable across industries.

Even though our independent variable is governmental discretion, multiple factors related to the firm, industry and host country can influence a firm's location choice. For this reason, we tried to include in our model all possible control variables at the firm, industry and host country levels. One of these control variables is macroeconomic uncertainty, which is an important factor when deciding whether to enter a country. Some previous studies showed that firms avoid macroeconomic uncertainty when investing abroad (Dunning, 1993), especially when the amount of investment is high (Campa, 1993). Following the methodology developed by Servén (1998) for measuring unexpected changes in economic growth, we calculated macroeconomic uncertainty as the logarithm of the conditional variance of GDP growth for a determined year, using the available information up to that moment. Specifically, we followed a GARCH $(1,1)$ model, which is widely used to calculate the volatility of different variables (Chua et al., 2011; Henisz, 2004). We formulated the model as follows:

$y_{i t}=\alpha_{1} t+\beta_{1} y_{i, t-1}+\varepsilon_{t}$

\footnotetext{
${ }^{1}$ This indicator includes motorways, highways and main or national roads, secondary or regional roads and all other roads in a country (we also included railway lines).
} 
$\sigma_{t}^{2}=\gamma_{i, 0}+\gamma_{i, 1} \varepsilon_{i, t-1}^{2}+\delta_{i} \sigma_{i, t-1}^{2}$

where $y_{i t}$ is the country GDP for a specific year $t$ and $\sigma^{2}$ is the variance of $\varepsilon_{t}$ conditioned on the available information up to year t. $\sigma^{2}$ was computed separately for each country. Another fact that may influence a firm's entry decision is whether the State is a shareholder. García-Canal and Guillén (2008) showed that regulated firms are heterogeneous in their aversion to taking risks, with those partially owned by the State more prone to risk taking. We thus created a dummy variable "Partial State ownership", valued at one when there is at least partial State ownership in the firm and valued at zero otherwise. To build this variable, we employed the information compiled by Vergés (1999, 2010).

The rest of the control variables included in the model are as follows. At the firm level, we introduced a firm's revenues as a control variable for firm size; the firm's experience in countries with highly discretionary governments (Delios and Henisz, 2003) measured as the number of entries in countries having highly discretionary governments ${ }^{3}$ made by the company as of the end of the previous year; and Tobin's q ratio, as a proxy for the intangible assets owned by the firm (Berry, 2006). To compute Tobin's q ratio, we followed the procedure described by Chung and Pruitt (1994). Firms' decisions to locate their investments in a particular country may be influenced by the experience of other companies investing there (Jiang et al., 2014; Knickerbocker, 1973). For this reason, we

\footnotetext{
${ }^{2}$ As our sample includes only listed firms, no firms are wholly owned by the State.

${ }^{3}$ We considered countries with highly discretionary governments those with a governmental discretion score above the median of the country set.
} 
included a variable that accounts for the number of investments made for the rest of the companies in the sample in a particular country as of the end of the previous year.

At the country level, we introduced the following variables. a) GDP at year 2000 constant prices to measure market size. b) GDP percent growth, to account for the host country's growth potential. c) The host country's attractiveness to foreign investors, measured as total inward FDI as a percentage of GDP. d) Imports plus exports as a percentage of GDP to account for openness to trade ${ }^{4}$. e) An index of corruption to control for other potential sources of risk $^{5}$. f) A dummy variable labeled "Developed country," valued at one when the firm invested in a country that is classified by both the World Bank and the IMF as developed - to account for the economic development of the host country, which may also influence firms' location choices — and valued at zero otherwise. g) A dummy variable valued at one if the firm invested in a country in the Latin America region and valued at zero otherwise - to control for the ease of doing business for Spanish firms in that area, due to cultural and/or political ties (Guillén, 2005). h) The geographic and economic distance between the home and host country ${ }^{6}$. And i) a dummy variable that indicates whether the host country has initiated an economic reform including privatization and deregulation processes, among others. To create the last variable, we used information from Lora (2000), Henisz et al. (2005) and Wallsten (2002). We also included industry, host country and year dummies. We used logarithms for the GDP and firm revenue

\footnotetext{
${ }^{4}$ These three variables were obtained from the database of the World Bank Indicators.

${ }^{5}$ We obtained this variable from the International Country Risk Guide database. We reversed the original index, which measured the lack of corruption, to have an indicator of the risk of being exposed to corruption.

${ }^{6}$ Data on these variables were obtained from the cross-national distance database developed by Berry et al. (2010). This information is electronically available from the Penn Lauder CIBER webpage.
} 
variables. Finally, governmental discretion, the infrastructure voids index and all control variables were lagged by one year.

\subsection{Method}

As our dependent variable is non-negative and integer-valued, using a Poisson regression instead of ordinary least squares is more appropriate to our panel data. To adjust for overdispersion, we used the negative binomial model, which is a generalization of the Poisson model. In this model, the assumption of equal mean and variance made in the Poisson model is relaxed (Cameron and Trivedi, 1998; Hausman et al., 1984). Finally, we used the fixed-effects specification of Hausman et al. (1984), which includes a timeinvariant variance-to-mean ratio for each firm (Allison and Waterman, 2002), to deal with the longitudinal character of the data. This fixed-effects specification and missing data for some variables reduced our effective sample to 68 firms that have made at least one entry in a foreign country. Table 1 shows the descriptive statistics and the correlation matrix of our variables. As the interaction terms had a high correlation with the main effect, we mean centered the continuous variables they included (Jaccard and Turrisi, 2003).

Insert Table 1 here

As we predict that RPIFs will be less deterred by governmental discretion than other firms when entering into a foreign country, we divided our full sample into two subsamples (regulated physical infrastructure and other industries) with the objective of analyzing the impact of governmental discretion on the investing behavior of each block of firms. 


\section{RESULTS}

Table 2 shows the results of the negative binomial regressions for the whole sample and for the firms from the regulated physical infrastructure and other industries subsamples. For the whole sample and the other industries subsample, there are two specifications of the model: control variables only and independent variables included. For the RPIFs subsample, there are three more specifications with the interaction effects included (specifications 3, 4 and 5).

Insert Table 2 here

We obtained support for almost all the hypotheses established in our model. Our prediction regarding the different behavior of firms from regulated physical infrastructure and from the remaining industries when facing governmental discretion (Hypothesis 1) received partial support. The difference between both coefficients of governmental discretion in the sample of regulated physical infrastructure and other industries is positive ( $\mathrm{b}_{1 \mathrm{RPIFs}}-\mathrm{b}_{1 \mathrm{tother}}$ firms $=1.51$ ) and significant, although at the 0.1 level (the coefficients used are those of the specification model 2 , for samples of both regulated physical infrastructure and the remaining firms). It is interesting to note that our results only show that for the case of RPIFs the negative effect of governmental discretion on a firm location choice is less negative than for other firms. Having said that, we cannot claim that RPIFs make more entries in countries where governmental discretion is high than in countries with less 
discretionary governments. In fact, on average, RPIFs do not increase their propensity to enter a specific country as governmental discretion increases, as the coefficient of this variable in model 2 in the RPIFs subsample shows. For the case of a RIF, a one standard deviation increase in governmental discretion would lead to a 15.39 percent decrease in the number of foreign entries. However, for the case of a firm in one of the remaining industries, the same increase in governmental discretion leads to a 45.88 percent reduction in the firm's foreign entries.

Our results also confirmed our prediction regarding the influence of the similarity of the legal origin of the home and host country national law systems (Hypothesis 2). In model 3, we found that the interaction effect between governmental discretion and civil code almost counteracts the negative impact of governmental discretion for RPIFs. This finding means that, for these companies, governmental discretion discourages entry in countries from a different legal family much more than in countries from the same legal family as the one of the home country, as predicted by our hypothesis. In fact, if the host country belongs to a non-civil code legal family, a firm's number of foreign entries decreases by 69.11 percent in response to a one standard deviation increase in governmental discretion. However, if the host country belongs to the civil code legal family, the firm's number of foreign entries only decreases by 9.97 percent in response to the same increase in governmental discretion.

The interaction between governmental discretion and infrastructure voids is positive as we predicted in our Hypothesis 3, but it is non-significant ( $\mathrm{p}=0.332$, model 4$)$. The joint moderating effect of the similarity of the legal origin of the home and host country national law systems and host country infrastructure voids stated in our fourth hypothesis is also 
supported (model 5). As the index of infrastructure voids is a continuous variable and the legal family is a dummy one, there are different scenarios for analyzing the magnitude of the effect of governmental discretion on the location choice decision. A RPIF investing in a host country within the civil code legal family makes 41.60 percent less foreign entries in response to a one standard deviation increase in governmental discretion in countries where the level of infrastructure voids is low (one standard deviation below the mean). However, if infrastructure voids are high (one standard deviation above the mean), a RPIF makes more entries in response to an increase in governmental discretion in those countries within the civil law legal family. In this situation, the willingness of a RPIF to enter in a foreign country turns positive and the same firm makes 13.12 percent foreign entries in response to a one standard deviation increase in governmental discretion. This is the only scenario in which RPIFs actually have a taste for governmental discretion, confirming our hypothesis 4. These results are also plotted in figures 2 and 3. Figure 2 shows the joint effect of the host country level of infrastructure voids and the legal family, when the host and home country belong to the same legal family. Figure 3 shows the joint effect of both variables when both countries do not belong to the same legal family.

Insert Figure 2 and 3 here

Most of the control variables have the expected sign. An interesting and, perhaps, clarifying result is the positive sign of the level of corruption that will be highlighted in the 
discussion section. The only control variable that is significant in all samples and almost in all model specifications is the firm's revenues.

\section{Robustness checks}

To rule out the possibility that our results could be driven by the definition of our dependent variable (the count of firm's entries in a particular country-year), we ran an additional regression by using a probit model in which the dependent variable is binary, valued at one when the firm invests at least once in a particular country-year and zero otherwise. Our results remained the same when using this alternative method (these results are available from the authors upon request).

In addition, and for the sake of comparison with the previous study of García-Canal and Guillén (2008), we also calculated our estimations for the same block of industries considered in their research as regulated - water, banking, telecommunications, electricity, petrol and gas. Using an alternative sample our results still hold (see Table 3).

Insert Table 3 here 
We were also concerned about the way in which we coded the legal family variable, as there are countries with hybrid legal systems. In this sense, we created an alternative variable valued at one when the host country has the civil code family or a hybrid system that involves the civil code family, and valued at zero otherwise. Then, we re-ran our regressions by using this alternative measure and found that our results remained unaltered.

We also used the executive constraints index (XCONST) of the POLITY IV database as an alternative indicator to the POLCONV. This index classifies governments according to the checks and balances they face along a multipoint scale ranging from 1 (for the less constrained executive) to 7 (for the most constrained one). This index uses less information than the POLCONV and is available for less country-year combinations, so its use reduces the size of our sample. Besides, unlike POLCONV, the XCONST does not incorporate the preferences of each veto player and the alignment among them. When using this alternative indicator, all of the parameters related to our hypotheses kept the expected sign, but those related to the first and second hypotheses were not significant. However, our third hypotheses, the one directly related to the boundary conditions for the exposure to governmental discretion, was confirmed. Results regarding these robustness checks are available from the authors upon request. Thus, our results are somehow contingent on the variable used to measure governmental discretion, although our boundary conditions for governmental discretion exposure still hold when changing it.

\section{DISCUSSION AND CONCLUSION}


Our paper reconciles two opposing views in the IB literature regarding the influence of governmental discretion on foreign location choice decisions. Whereas the traditional view argues that firms tend to avoid governmental discretion when choosing the destination of their FDI, recent research shows that some firms contemplate as a profitable choice the exposure to this risk. Our results contribute to this literature by identifying under what circumstances firms in regulated physical infrastructure industries show a preference for countries where governmental discretion is high. On the one hand, our results show that the insight from received theory regarding the influence of governmental discretion on location choice still apply, as we found that, overall, firms avoid investing in countries with discretionary governments. On the other hand, our findings also show that some exceptions to this general rule exist, as some firms are willing to embrace and to be exposed to governmental discretion under some specific conditions.

The theoretical framework developed in this paper allowed us to explain whether and why RPIFs could be willing to face the risks associated with governmental discretion. We argued that thanks to their more developed political capabilities, RPIFs are less vulnerable to governmental discretion than the remaining firms when entering a foreign country. We also show that these firms certainly have a taste for governmental discretion if the host and home country belong to the same legal family and the host country has high infrastructure voids.

Taking as starting point the evidence regarding the propensity of RPIFs to enter into countries with governments enjoying ample discretion (García-Canal and Guillén, 2008; Holburn and Zelner, 2010; Jiménez et al., 2014), our main contribution to the literature is to develop and test a theoretical framework based on organizational capabilities 
to identify the boundary conditions of this risk-seeking behavior. We argue that this investment pattern can be explained by taking into account that these firms accumulate, on average, more political capabilities than other firms.

One important implication of our analysis is that firms used to dealing with governments and regulators in a particular legal family are in a better position to reduce the uncertainty associated with governmental discretion in countries from the same legal family than in others belonging to a different one. For this reason, our paper contributes to the literature on the effect of firms' institutional experience on FDI. In a recent paper, Perkins (2014) highlighted the main role of firms' institutional experience in the survival of FDI, although she referred to the knowledge that firms accumulate across host countries. We contribute to this line of research by showing that the institutional experience accumulated at home plays a major role in firms' location choices and that this experience is only valuable in host countries with a similar institutional environment.

Our study also contributes to the literature by extending the RBV, and particularly the organizational capabilities view of the firm, to the non-market environment (Boddewyn and Brewer, 1994; Bonardi, 2011; Henisz and Zelner, 2012; Holburn and Zelner, 2010; Lawton et al., 2013; Oliver and Holzinger, 2008). Our results go in the same direction as recent studies considering that some firms can leverage abroad the knowledge that they have developed at home in dealing with governments and regulators (Bonardi, 2004; Buckley et al., 2007; Cuervo-Cazurra and Genc, 2008; García-Canal and Guillén, 2008; Holburn and Zelner, 2010; Kothari et al., 2013). We contribute to this literature by focusing on cross-industry differences in political capabilities and identifying the conditions under with these capabilities are more effective. 
In this sense, our paper also contributes to the extant literature on the role that political capabilities play on the specific case of RPIFs' international expansion. Holburn and Zelner (2010) proxied political capabilities through the experience accumulated at home by electric power-generation firms across the world. They found cross-national differences in the willingness to invest in countries with governmental discretion. Firms coming from countries where governmental discretion was high showed a greater probability to invest in countries with highly discretionary governments than firms from countries with stronger institutional constraints. By comparing regulated physical infrastructure and other firms, and focusing in just one country of origin, our analysis shows that firm's political capability endowment also vary across industries.

Our paper is the first to show the effect of host country infrastructure voids on RPIFs ' location choices in the presence of governmental discretion. The conventional wisdom is that high levels of infrastructure development attract FDI (Flores and Aguilera, 2007). However, we show, for the particular case of regulated physical infrastructure companies, that infrastructure voids generate growth opportunities in the foreign country. A high level of infrastructure voids in the host country attracts FDI from RPIFs when coupled with governmental discretion and the host country belonging to the same legal family as the home country.

However, infrastructure voids per se do not attract FDI from RPIFs in countries with discretionary governments. Our results show that a high level of infrastructure voids in countries with discretionary governments only attracts incoming FDI from firms from countries from the same legal family. It is in these cases when RPIFs can effectively employ their political capabilities to get favorable outcomes in their negotiations with host 
governments. When these capabilities cannot be effectively used, as happens in countries from a different legal family, FDI is discouraged (see Figures 2 and 3 for a comparison of the moderating effects of infrastructure voids in countries from the civil code legal family and in countries from a different legal family). The main implication of this result is that in regulated physical infrastructure industries a time window exists during which firms can successfully exploit their political capabilities in countries from the same legal family: the period in which infrastructure voids are high. In this situation, firms can effectively exploit these capabilities to obtain rents. However, governmental discretion may turn into a disadvantage as the host country's level of infrastructure voids decreases, because there is less room for firms to fully exploit their political capabilities. The different indicators of infrastructure voids for each RPIF are an empirical contribution of this paper.

One of the main antecedents of this paper is García-Canal and Guillén (2008), which also used data from Spain. Compared to their paper, ours not only provides a more developed framework, but also makes use of a more complete dataset. Whereas they analyzed only Spanish firms from regulated physical infrastructure industries investing in Latin America from 1987 to 2000, we have panel data from 1986 to 2008 of firms from regulated infrastructure and other industries investing across the world. Thanks to our richer data, we can test more hypotheses than they did, clarifying also some of the evidence they collected. Specifically, our data show that the general propensity of RPIFs to enter into countries with discretionary governments observed in their paper is no longer present. This discrepancy can be explained taking into account that they analyzed only investments from regulated firms in Latin America (where variance on civil code variable is very low, as almost all countries in this region belong to this legal family), and during a period were 
infrastructure voids were high. By considering more variance on the legal family and infrastructure voids variables, we were able to develop a more refined framework in which the critical moderating role of these variables is taken into account. Our paper, thus, makes an empirical and theoretical contribution, as compared to previous literature on this topic. It is also interesting to notice that this attraction for countries where governmental discretion is high is not exclusive from emerging market multinationals (Cuervo-Cazurra and Genc, 2008), but also for firms from countries having stronger institutions, like Spain.

The fact that our results are robust when using alternative classification of regulated industries shows not only their mere robustness, but also that not only firms in the core of regulated physical infrastructure industries develop political capabilities valid for dealing with governmental discretion. This interesting issue deserves more attention. Firms accumulate political capabilities as they interact with governments and regulators in their home country. The higher the degree of regulation of their industry, the higher the odds of developing such capabilities. Thus, regulation is a continuous variable that changes across industries and countries. RPIFs could be considered as one extreme of this continuum. In addition, not all firms are equally active in corporate political activities, so not all firms exposed to regulation accumulate political capabilities in the same way. For these reasons, future studies developing more refined measurements of regulation and political capabilities can shed more light on the drivers of FDI in countries with governmental discretion.

Our result on the level of corruption is also interesting as this host-country attribute clearly attracts foreign investments from all kind of firms. The positive and significant coefficient of this variable is consistent with previous research on the internationalization of 
Spanish firms (Jiménez, 2010; Jiménez et al., 2014) and firms from emerging countries (Cuervo-Cazurra and Genc, 2008). However, what is interesting in this result is that governmental discretion and corruption have a different overall effect on firms' propensity to invest abroad. In addition, by including this variable in the regression, we can rule out that our results regarding RPIFs' willingness to be exposed to governmental discretion are explained by corruption. Even though, sometimes, governmental discretion and corruption go hand by hand, our results clarify the impact of these two attributes of host governments on the willingness to enter a foreign country.

This paper is not without limitations. The first one is that our results are contingent on the variable we used to measure governmental discretion as we stated before. Other limitation of this paper is that we were not able to measure directly political capabilities. We proxied them by considering that firms from regulated physical infrastructure industries have more political capabilities than the remaining ones. From this limitation, as stated above, emerges a promising future line of research, that of measuring political capabilities. These capabilities could be measured by focusing on the non-market strategy of a firm in its home country. Another limitation of our paper is that we only analyzed firms from one country, so further studies including more home countries are required. Another future line of research is the study of the outcomes of FDI in regulated infrastructure industries. In addition, the positive sign of the level of corruption should be addressed in future research, as it is an interesting and intriguing result that deserves more attention. 
Figure 1. Causal relationships established in our theory for the relationship between governmental discretion and FDI in regulated physical infrastructure industries

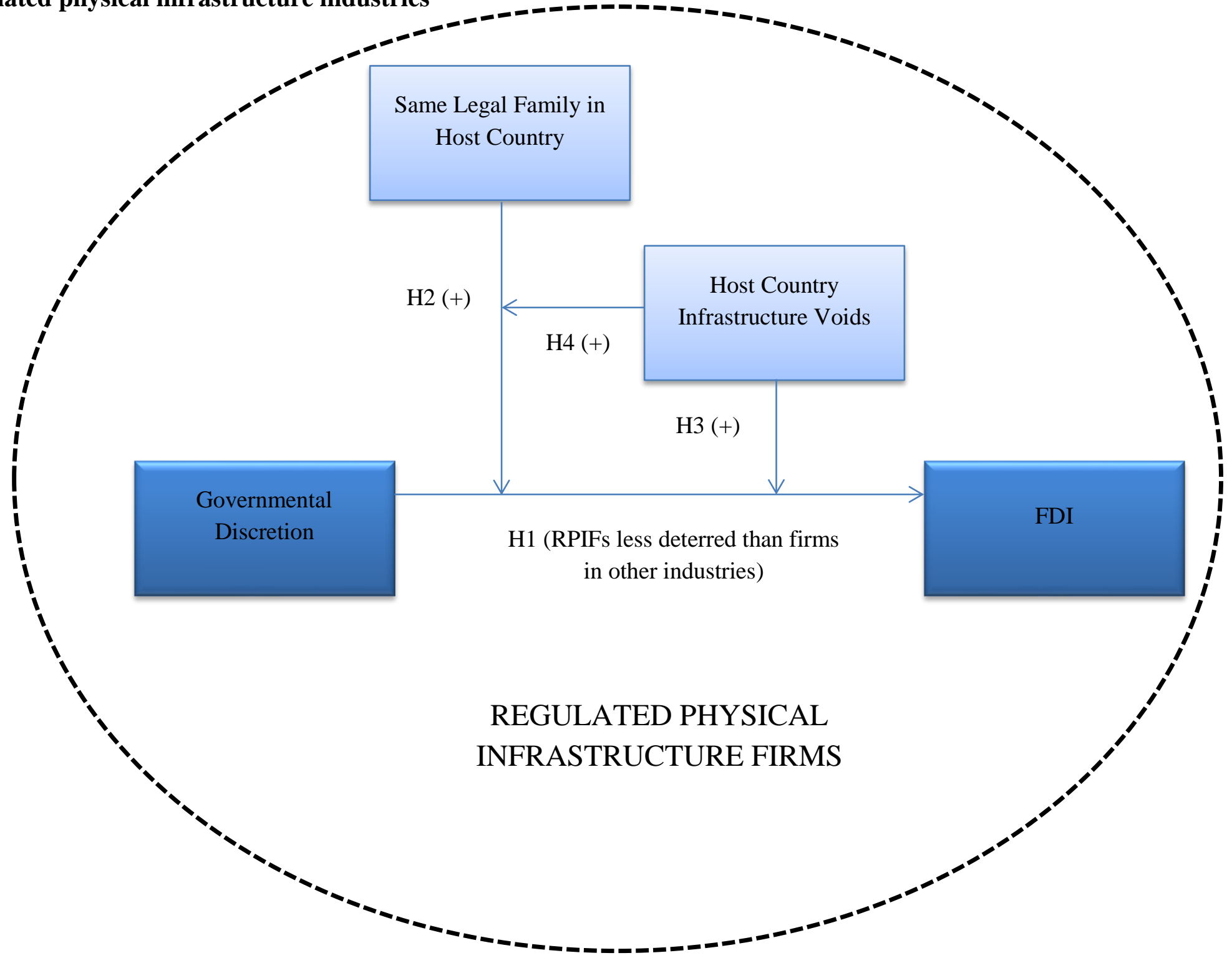


Table 1. Descriptive statistics and correlations of the RPIFs sample (the rest of matrices for the rest of samples are available from the authors upon request)

Variables
1 Firm entries-country-year
2 Governmental discretion
3 Civil code
4 Infrastructure voids
5 Firm's experience in countries with discretionary governments
$\mathbf{6}$ Other firms' experience in the host country
$\mathbf{7}$ Partial State ownership
$\mathbf{8}$ Firm's Tobin's q
9 Firm's revenues
$\mathbf{1 0}$ Host country's macroeconomic uncertainty
$\mathbf{1 1}$ Developed country
$\mathbf{1 2}$ Host country's corruption level
$\mathbf{1 3}$ LATAM
$\mathbf{1 4}$ Geographic distance
$\mathbf{1 5}$ Economic distance
$\mathbf{1 6}$ Host country's GDP
$\mathbf{1 7}$ Host country's GDP growth
$\mathbf{1 8}$ Host country's FDI inward
$\mathbf{1 9}$ Host country's trade openness
$\mathbf{2 0}$ Host country's market reforms initiated
Note: * p-value 0.05 or lower.

$\begin{array}{ccccccccccc}\text { Mean } & \text { Std. Dev. } & \mathbf{1} & \mathbf{2} & \mathbf{3} & \mathbf{4} & \mathbf{5} & \mathbf{6} & \mathbf{7} & \mathbf{8} & \mathbf{9} \\ 0.05 & 0.30 & 1 & & & & & & & & \\ 1.04 \mathrm{E}-09 & 0.29 & -0.05^{*} & 1 & & & & & & & \\ 0.52 & 0.50 & 0.08^{*} & 0.18^{*} & 1 & & & & & & \\ 5.84 \mathrm{E}-10 & 0.23 & 0.01 & 0.17^{*} & 0.11^{*} & 1 & & & & & \\ 6.40 & 9.46 & 0.10^{*} & -0.02^{*} & -0.02^{*} & 0.00 & 1 & & & & \\ 8.28 & 18.92 & 0.28^{*} & -0.16^{*} & 0.24^{*} & -0.04^{*} & 0.20^{*} & 1 & & & \\ 0.16 & 0.37 & -0.02^{*} & 0.01^{*} & 0.01 & 0.17^{*} & -0.22^{*} & -0.11^{*} & 1 & & \\ 1.31 & 0.40 & 0.05^{*} & -0.05^{*} & -0.01 & -0.13^{*} & 0.22^{*} & 0.12^{*} & -0.16^{*} & 1 & \\ 8.03 & 1.44 & 0.10^{*} & -0.02^{*} & -0.00 & 0.07^{*} & 0.62^{*} & 0.14^{*} & 0.03^{*} & 0.16^{*} & 1 \\ -7.26 & 1.20 & -0.01 & 0.22^{*} & 0.16^{*} & 0.07^{*} & -0.11^{*} & -0.04^{*} & 0.07^{*} & -0.07^{*} & -0.07^{*} \\ 0.32 & 0.47 & 0.03^{*} & -0.54^{*} & -0.25^{*} & -0.24^{*} & -0.00 & 0.11^{*} & -0.01 & -0.00 & -0.01 \\ 2.62 & 1.37 & 0.01^{*} & 0.56^{*} & 0.25^{*} & 0.18^{*} & 0.20^{*} & 0.01 & -0.11^{*} & 0.11^{*} & 0.14^{*} \\ 0.25 & 0.43 & 0.08^{*} & -0.01 & 0.50^{*} & 0.09^{*} & -0.04^{*} & 0.21^{*} & 0.03^{*} & -0.02^{*} & -0.01 \\ 5834.83 & 3901.63 & 0.00 & 0.05^{*} & -0.09^{*} & 0.03^{*} & -0.02^{*} & -0.01 & 0.01 & -0.01 & -0.01 \\ 4.45 & 5.85 & -0.05^{*} & -0.01 & -0.10^{*} & -0.06^{*} & 0.16^{*} & -0.12^{*} & -0.07^{*} & 0.07^{*} & 0.11^{*} \\ 24.51 & 1.98 & 0.14^{*} & -0.38^{*} & -0.15^{*} & -0.13^{*} & 0.06^{*} & 0.40^{*} & -0.03^{*} & 0.03^{*} & 0.04^{*} \\ 3.76 & 4.02 & 0.00 & 0.07^{*} & -0.06^{*} & -0.01 & 0.15^{*} & -0.04^{*} & -0.06^{*} & 0.08^{*} & 0.11^{*} \\ 6.04 & 32.36 & -0.01 & -0.09^{*} & 0.08^{*} & -0.06^{*} & 0.06^{*} & -0.03^{*} & -0.04^{*} & 0.04^{*} & 0.04^{*} \\ 76.03 & 47.43 & -0.08^{*} & -0.08^{*} & -0.09^{*} & -0.08^{*} & 0.14^{*} & -0.18^{*} & -0.07^{*} & 0.07^{*} & 0.10^{*} \\ 0.59 & 0.49 & 0.10^{*} & -0.09^{*} & 0.01 & -0.06^{*} & 0.21^{*} & 0.28^{*} & -0.12^{*} & 0.16^{*} & 0.15^{*}\end{array}$




\section{Table 1 (Continued)}

\section{Variables}

10 Host country's macroeconomic uncertainty

11 Developed country

12 Host country's corruption level

13 LATAM

14 Geographic distance

15 Economic distance

16 Host country's GDP

17 Host country's GDP growth

18 Host country's FDI inward

19 Host country's trade openness

20 Host country's market reforms initiated

$\begin{array}{cc}\text { Mean } & \text { Std. Dev. } \\ -7.26 & 1.20 \\ 0.32 & 0.47 \\ 2.62 & 1.37 \\ 0.25 & 0.43 \\ 5834.83 & 3901.63 \\ 4.45 & 5.85 \\ 24.51 & 1.98 \\ 3.76 & 4.02 \\ 6.04 & 32.36 \\ 76.03 & 47.43 \\ 0.59 & 0.49\end{array}$

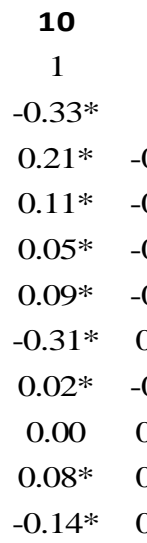

11

12

13

14

15

16

Note: * p-value 0.05 or lower. 
Table 2. Firm fixed-effects negative binomial regressions predicting foreign country entry

\begin{tabular}{|c|c|c|c|c|c|c|c|c|c|c|}
\hline & & \multicolumn{2}{|c|}{ All firms } & \multicolumn{2}{|c|}{ Other firms } & \multicolumn{5}{|c|}{ RPIFs } \\
\hline & VARIABLES & $(1)$ & $(2)$ & $(1)$ & $(2)$ & $(1)$ & $(2)$ & $(3)$ & $(4)$ & $(5)$ \\
\hline $\mathrm{b}_{1}$ & Governmental discretion $\mathrm{H} 1:\left(\mathrm{H}_{0}: \mathrm{b}_{1 . \mathrm{RPIFs}}-\mathrm{b}_{1 \text { other firms }}=0\right)$ & & $\begin{array}{l}-0.98 * * * \\
(-2.74)\end{array}$ & & $\begin{array}{c}-2.08 * * * \\
(-3.09)\end{array}$ & & $\begin{array}{l}-0.57 \\
(-1.26)\end{array}$ & $\begin{array}{l}-3.99 * * \\
(-2.21)\end{array}$ & $\begin{array}{l}-0.62 \\
(-1.37)\end{array}$ & $\begin{array}{l}-3.97 * * \\
(-2.20)\end{array}$ \\
\hline $\mathrm{b}_{2}$ & Governmental discretion $x$ Civil code $(\mathrm{H} 2+)$ & & & & & & & $\begin{array}{c}3.63 * * \\
(1.98)\end{array}$ & & $\begin{array}{c}3.27 * \\
(1.77)\end{array}$ \\
\hline$b_{3}$ & Governmental discretion $\mathrm{x}$ Infrastructure voids $(\mathrm{H} 3+)$ & & & & & & & & $\begin{array}{c}1.05 \\
(0.97)\end{array}$ & $\begin{array}{c}-2.40 * * \\
(-2.28)\end{array}$ \\
\hline $\mathrm{b}_{4}$ & $\begin{array}{l}\text { Governmental discretion x Civil code } \mathrm{x} \text { Infrastructure } \\
\text { voids }(\mathrm{H} 4+)\end{array}$ & & & & & & & & & $7.23 * * *$ \\
\hline$b_{5}$ & Civil code $\mathrm{x}$ Infrastructure voids & & & & & & & & & $\begin{array}{c}(3.38) \\
1.72 * * * \\
(3.20)\end{array}$ \\
\hline $\mathrm{b}_{6}$ & Civil code & $\begin{array}{c}-7.69 \\
(-0.71)\end{array}$ & $\begin{array}{l}-3.84 \\
(-0.35)\end{array}$ & $\begin{array}{l}99.03 \\
(0.00)\end{array}$ & $\begin{array}{c}113.49 \\
(0.00)\end{array}$ & $\begin{array}{l}-7.48 \\
(-0.56)\end{array}$ & $\begin{array}{l}-5.09 \\
(-0.38)\end{array}$ & $\begin{array}{l}-5.91 \\
(-0.44)\end{array}$ & $\begin{array}{l}-5.53 \\
(-0.41)\end{array}$ & $\begin{array}{l}-6.08 \\
(-0.45)\end{array}$ \\
\hline$b_{7}$ & Infrastructure voids $^{1}$ & & & & & $\begin{array}{c}1.03 * * * \\
(2.85)\end{array}$ & $\begin{array}{c}1.03 * * * \\
(2.84)\end{array}$ & $\begin{array}{l}1.04 * * * \\
(2.87)\end{array}$ & $\begin{array}{c}1.20 * * * \\
(2.96)\end{array}$ & $\begin{array}{c}0.10 \\
(0.21)\end{array}$ \\
\hline $\mathrm{b}_{8}$ & $\begin{array}{l}\text { Firm's experience in countries with discretionary } \\
\text { governments }\end{array}$ & -0.00 & -0.00 & $-0.13 * * *$ & $-0.15 * * *$ & -0.00 & -0.00 & -0.00 & -0.00 & -0.00 \\
\hline & & $(-0.08)$ & $(-0.08)$ & $(-2.80)$ & $(-3.09)$ & $(-0.16)$ & $(-0.17)$ & $(-0.17)$ & $(-0.17)$ & $(-0.22)$ \\
\hline$b_{9}$ & Other firms' experience in the host country & $\begin{array}{l}-0.00 * \\
(-1.73)\end{array}$ & $\begin{array}{c}-0.00 * * \\
(-1.99)\end{array}$ & $\begin{array}{c}-0.00 \\
(-0.37)\end{array}$ & $\begin{array}{c}-0.00 \\
(-0.76)\end{array}$ & $\begin{array}{l}-0.01 * \\
(-1.71)\end{array}$ & $\begin{array}{l}-0.01 * \\
(-1.80)\end{array}$ & $\begin{array}{l}-0.01 * \\
(-1.94)\end{array}$ & $\begin{array}{l}-0.01 * \\
(-1.82)\end{array}$ & $\begin{array}{c}-0.01 * * \\
(-1.99)\end{array}$ \\
\hline $\mathrm{b}_{10}$ & Partial State ownership & $\begin{array}{c}0.40 * * * \\
(2.67)\end{array}$ & $\begin{array}{c}0.40 * * * \\
(2.67)\end{array}$ & $\begin{array}{c}-0.19 \\
(-0.44)\end{array}$ & $\begin{array}{c}-0.27 \\
(-0.60)\end{array}$ & $\begin{array}{c}0.38 * * \\
(2.16)\end{array}$ & $\begin{array}{c}0.38^{* *} \\
(2.15)\end{array}$ & $\begin{array}{c}0.38 * * \\
(2.15)\end{array}$ & $\begin{array}{c}0.38 * * \\
(2.15)\end{array}$ & $\begin{array}{c}0.38 * * \\
(2.16)\end{array}$ \\
\hline$b_{11}$ & Firm's Tobin's q & $\begin{array}{c}0.08 \\
(1.01)\end{array}$ & $\begin{array}{c}0.08 \\
(1.04)\end{array}$ & $\begin{array}{c}-0.03 \\
(-0.30)\end{array}$ & $\begin{array}{c}-0.02 \\
(-0.23)\end{array}$ & $\begin{array}{c}0.43 * * \\
(2.57)\end{array}$ & $\begin{array}{c}0.43 * * * \\
(2.59)\end{array}$ & $\begin{array}{c}0.43 * * * \\
(2.59)\end{array}$ & $\begin{array}{c}0.43 * * * \\
(2.58)\end{array}$ & $\begin{array}{c}0.44 * * * \\
(2.64)\end{array}$ \\
\hline$b_{12}$ & Firm's revenues & $\begin{array}{c}0.29 * * * \\
(3.55)\end{array}$ & $\begin{array}{c}0.29 * * * \\
(3.55)\end{array}$ & $\begin{array}{l}0.21 * \\
(1.77)\end{array}$ & $\begin{array}{c}0.15 \\
(1.30)\end{array}$ & $\begin{array}{c}0.37 * * * \\
(2.75)\end{array}$ & $\begin{array}{c}0.36 * * * \\
(2.75)\end{array}$ & $\begin{array}{c}0.36 * * * \\
(2.74)\end{array}$ & $\begin{array}{c}0.36 * * * \\
(2.73)\end{array}$ & $\begin{array}{c}0.37 * * * \\
(2.74)\end{array}$ \\
\hline
\end{tabular}

${ }^{1}$ Infrastructure voids can be only calculated for RPIFs subsample. 
Table 2 (Continued)

\begin{tabular}{|c|c|c|c|c|c|c|c|c|c|c|}
\hline & \multirow[b]{2}{*}{ VARIABLES } & \multicolumn{2}{|c|}{ All firms } & \multicolumn{2}{|c|}{ Other firms } & \multicolumn{5}{|c|}{ RPIFs } \\
\hline & & $(1)$ & $(2)$ & $(1)$ & $(2)$ & $(1)$ & $(2)$ & $(3)$ & $(4)$ & $(5)$ \\
\hline \multirow[t]{2}{*}{$b_{13}$} & Host country's macroeconomic uncertainty & 0.03 & 0.04 & 0.08 & 0.09 & 0.01 & 0.01 & 0.01 & 0.01 & 0.01 \\
\hline & & $(0.46)$ & $(0.64)$ & $(0.68)$ & $(0.79)$ & $(0.07)$ & $(0.16)$ & $(0.11)$ & $(0.18)$ & $(0.19)$ \\
\hline \multirow{2}{*}{$b_{14}$} & Developed country & -1.45 & -0.45 & 5.42 & 7.45 & 0.66 & 1.29 & 0.62 & 1.14 & 0.64 \\
\hline & & $(-0.55)$ & $(-0.17)$ & $(0.00)$ & $(0.00)$ & $(0.19)$ & $(0.38)$ & $(0.18)$ & $(0.33)$ & $(0.19)$ \\
\hline \multirow[t]{2}{*}{$b_{15}$} & Host country's corruption level & $0.21 * * *$ & $0.25 * * *$ & $0.36 * * *$ & $0.43 * * *$ & $0.14 *$ & $0.16 * *$ & $0.17 * *$ & $0.16 * *$ & $0.17 * *$ \\
\hline & & (3.39) & $(3.86)$ & $(3.08)$ & $(3.56)$ & $(1.79)$ & $(2.00)$ & $(2.11)$ & $(2.02)$ & $(2.16)$ \\
\hline \multirow[t]{2}{*}{$b_{16}$} & LATAM & 7.54 & 4.44 & -82.97 & -94.77 & 8.32 & 6.40 & 7.67 & 6.77 & 7.78 \\
\hline & & $(0.84)$ & $(0.49)$ & $(-0.00)$ & $(-0.00)$ & $(0.75)$ & $(0.57)$ & $(0.67)$ & $(0.60)$ & $(0.68)$ \\
\hline \multirow[t]{2}{*}{$b_{17}$} & Geographic distance & -0.00 & -0.00 & 0.01 & 0.02 & -0.00 & -0.00 & -0.00 & -0.00 & -0.00 \\
\hline & & $(-0.80)$ & $(-0.47)$ & $(0.00)$ & $(0.00)$ & $(-0.59)$ & $(-0.42)$ & $(-0.53)$ & $(-0.46)$ & $(-0.53)$ \\
\hline \multirow[t]{2}{*}{$\mathrm{b}_{18}$} & Economic distance & 0.01 & 0.01 & 0.03 & 0.05 & 0.00 & 0.00 & 0.00 & 0.00 & -0.00 \\
\hline & & $(0.17)$ & $(0.31)$ & $(0.41)$ & $(0.76)$ & $(0.00)$ & $(0.05)$ & $(0.02)$ & $(0.02)$ & $(-0.02)$ \\
\hline \multirow[t]{2}{*}{$b_{19}$} & Host country's GDP & $0.85 * *$ & 0.67 & $1.25^{*}$ & 0.98 & 0.46 & 0.35 & 0.39 & 0.37 & 0.38 \\
\hline & & $(2.01)$ & $(1.56)$ & $(1.66)$ & $(1.26)$ & $(0.86)$ & $(0.64)$ & $(0.71)$ & $(0.68)$ & $(0.70)$ \\
\hline \multirow[t]{2}{*}{$b_{20}$} & Host country's GDP growth & -0.01 & -0.00 & -0.00 & 0.01 & -0.01 & -0.00 & -0.00 & -0.00 & -0.00 \\
\hline & & $(-0.46)$ & $(-0.09)$ & $(-0.01)$ & $(0.37)$ & $(-0.35)$ & $(-0.14)$ & $(-0.16)$ & $(-0.12)$ & $(-0.06)$ \\
\hline \multirow[t]{2}{*}{$b_{21}$} & Host country's FDI inward & 0.00 & 0.00 & -0.01 & -0.01 & $0.04 * * *$ & $0.04 * * *$ & $0.04 * * *$ & $0.04 * * *$ & $0.04 * * *$ \\
\hline & & $(0.58)$ & $(0.45)$ & $(-0.81)$ & $(-1.02)$ & (3.39) & $(3.26)$ & $(3.27)$ & $(3.25)$ & $(3.25)$ \\
\hline \multirow[t]{2}{*}{$b_{22}$} & Host country's trade openness & -0.00 & -0.00 & 0.00 & -0.00 & -0.01 & -0.01 & $-0.01 *$ & -0.01 & $-0.01 *$ \\
\hline & & $(-0.78)$ & $(-0.89)$ & $(0.01)$ & $(-0.38)$ & $(-1.52)$ & $(-1.53)$ & $(-1.71)$ & $(-1.52)$ & $(-1.72)$ \\
\hline \multirow[t]{8}{*}{$b_{23}$} & Host country's market reforms initiated & 0.33 & 0.32 & 0.02 & -0.08 & $0.56 * *$ & $0.55 * *$ & $0.53 *$ & $0.55 * *$ & $0.52 *$ \\
\hline & & $(1.63)$ & $(1.56)$ & $(0.07)$ & $(-0.24)$ & $(2.01)$ & (1.99) & $(1.90)$ & $(1.98)$ & $(1.86)$ \\
\hline & Constant & $-16.44 * *$ & $-16.26 * *$ & -151.68 & -162.19 & -8.55 & -8.47 & -8.27 & -8.44 & -8.06 \\
\hline & & $(-2.12)$ & $(-2.10)$ & $(-0.00)$ & $(-0.00)$ & $(-0.98)$ & $(-0.97)$ & $(-0.95)$ & $(-0.97)$ & $(-0.92)$ \\
\hline & $\begin{array}{l}\text { Difference in coefficients Ho: } b_{1 \text { RPIFs }}-b_{1 \text { other firms }}=0 \\
t \text { value of difference }\end{array}$ & & & & & & $\begin{array}{l}1.51^{*} \\
(1.87)\end{array}$ & & & \\
\hline & Observations & 70,415 & 70,415 & 52,412 & 52,412 & 16,270 & 16,270 & 16,270 & 16,270 & 16,270 \\
\hline & Number of firms & 59 & 59 & 45 & 45 & 14 & 14 & 14 & 14 & 14 \\
\hline & Log likelihood & -3954.89 & -3950.92 & -1564.17 & -1537.66 & -2174.70 & -2173.88 & -2171.74 & -2173.38 & -2163.79 \\
\hline
\end{tabular}

Note: $* * * * \mathrm{p}<0.001, * * * \mathrm{p}<0.01,{ }^{* *} \mathrm{p}<0.05, * \mathrm{p}<0.1 . \mathrm{z}$-statistics in parentheses 
Table 3. Firm fixed-effects negative binomial regressions predicting foreign country entry for the alternative RPIFs' sample

\begin{tabular}{|c|c|c|c|c|c|c|}
\hline & \multirow[b]{2}{*}{ VARIABLES } & \multicolumn{5}{|c|}{ GC\&G industries } \\
\hline & & (1) & (2) & (3) & (4) & (5) \\
\hline$b_{1}$ & $\begin{array}{l}\text { Governmental discretion H1: (Ho: } b_{1 . G C \& G}-b_{1 \text { other }} \\
\text { firms }=0)\end{array}$ & & $-0.73 *$ & $-4.33 * *$ & $-0.77 *$ & $-4.33 * *$ \\
\hline & & & $(-1.71)$ & $(-2.58)$ & $(-1.81)$ & $(-2.57)$ \\
\hline$b_{2}$ & Governmental discretion x Civil code $(\mathrm{H} 2+)$ & & & $\begin{array}{l}3.82 * * \\
(2.24)\end{array}$ & & $\begin{array}{l}3.57 * * \\
(2.08)\end{array}$ \\
\hline$b_{3}$ & Governmental discretion $\mathrm{x}$ Infrastructure voids $(\mathrm{H} 3+)$ & & & & $\begin{array}{c}1.29 \\
(1.19)\end{array}$ & $\begin{array}{l}-2.48 * * \\
(-2.38)\end{array}$ \\
\hline $\mathrm{b}_{4}$ & $\begin{array}{l}\text { Governmental discretion x Civil code x Infrastructure } \\
\text { voids }(\mathrm{H} 4+)\end{array}$ & & & & & $\begin{array}{c}7.33 * * * \\
(3.55)\end{array}$ \\
\hline$b_{5}$ & Civil code $x$ Infrastructure voids & & & & & $\begin{array}{c}2.03 * * * \\
(3.76)\end{array}$ \\
\hline $\mathrm{b}_{6}$ & Civil code & $\begin{array}{l}-22.65^{*} \\
(-1.69)\end{array}$ & $\begin{array}{l}-18.16 \\
(-1.33)\end{array}$ & $\begin{array}{l}-20.28 \\
(-1.46)\end{array}$ & $\begin{array}{l}-18.79 \\
(-1.38)\end{array}$ & $\begin{array}{l}-21.70 \\
(-1.56)\end{array}$ \\
\hline $\mathrm{b}_{7}$ & Infrastructure voids & $\begin{array}{l}0.65 \\
(1.64)\end{array}$ & $\begin{array}{l}0.65 \\
(1.62)\end{array}$ & $\begin{array}{l}0.66^{*} \\
(1.66)\end{array}$ & $\begin{array}{l}0.84^{*} \\
(1.94)\end{array}$ & $\begin{array}{l}-0.58 \\
(-1.08)\end{array}$ \\
\hline$b_{8}$ & $\begin{array}{l}\text { Firm's experience in countries with discretionary } \\
\text { governments }\end{array}$ & -0.01 & -0.01 & -0.01 & -0.01 & -0.01 \\
\hline & & $(-0.76)$ & $(-0.76)$ & $(-0.77)$ & $(-0.78)$ & $(-0.82)$ \\
\hline $\mathrm{b}_{9}$ & Other firms' experience in the host country & $\begin{array}{l}-0.01 * * \\
(-2.17)\end{array}$ & $\begin{array}{l}-0.01 * * \\
(-2.32)\end{array}$ & $\begin{array}{l}-0.01 * * \\
(-2.47)\end{array}$ & $\begin{array}{r}-0.01 * * \\
(-2.35)\end{array}$ & $\begin{array}{l}-0.01 * * \\
(-2.45)\end{array}$ \\
\hline$b_{10}$ & Partial State ownership & $\begin{array}{c}0.19 \\
(1.04)\end{array}$ & $\begin{array}{l}0.19 \\
(1.04)\end{array}$ & $\begin{array}{c}0.19 \\
(1.04)\end{array}$ & $\begin{array}{c}0.19 \\
(1.04)\end{array}$ & $\begin{array}{c}0.19 \\
(1.04)\end{array}$ \\
\hline$b_{11}$ & Firm's Tobin's q & $\begin{array}{l}0.46 * * * \\
(3.39)\end{array}$ & $\begin{array}{l}0.46^{* * * *} \\
(3.41)\end{array}$ & $\begin{array}{l}0.46 * * * \\
(3.42)\end{array}$ & $\begin{array}{c}0.46 * * * \\
(3.40)\end{array}$ & $\begin{array}{c}0.47 * * * \\
(3.44)\end{array}$ \\
\hline$b_{12}$ & Firm's revenues & $\begin{array}{c}0.41 * * * \\
(3.15)\end{array}$ & $\begin{array}{c}0.41 * * * \\
(3.15)\end{array}$ & $\begin{array}{c}0.41 * * * \\
(3.15)\end{array}$ & $\begin{array}{c}0.41 * * * \\
(3.15)\end{array}$ & $\begin{array}{c}0.41 * * * \\
(3.13)\end{array}$ \\
\hline
\end{tabular}

${ }^{1}$ For the case of the banking industry, we calculated the infrastructure voids variable using the indicator of the bank private credit as a percentage of GDP. We obtained the data for this indicator from de World Bank Indicators Database. 
Table 3 (Continued)

\begin{tabular}{|c|c|c|c|c|c|c|}
\hline \multirow{2}{*}{\multicolumn{2}{|c|}{ VARIABLES }} & \multicolumn{5}{|c|}{ GC\&G industries } \\
\hline & & $(1)$ & $(2)$ & $(3)$ & $(4)$ & $(5)$ \\
\hline \multirow[t]{2}{*}{$b_{13}$} & Host country's macroeconomic uncertainty & -0.04 & -0.03 & -0.04 & -0.03 & -0.03 \\
\hline & & $(-0.55)$ & $(-0.45)$ & $(-0.47)$ & $(-0.42)$ & $(-0.37)$ \\
\hline \multirow[t]{2}{*}{$\mathrm{b}_{14}$} & Developed country & -1.98 & -0.76 & -1.83 & -0.95 & -2.15 \\
\hline & & $(-0.60)$ & $(-0.23)$ & $(-0.53)$ & $(-0.28)$ & $(-0.63)$ \\
\hline \multirow[t]{2}{*}{$\mathrm{b}_{15}$} & Host country's corruption level & $0.14 *$ & $0.17 * *$ & $0.18 * *$ & $0.17 * *$ & $0.19 * *$ \\
\hline & & $(1.88)$ & $(2.16)$ & $(2.35)$ & $(2.17)$ & $(2.37)$ \\
\hline \multirow[t]{2}{*}{$\mathrm{b}_{16}$} & LATAM & $21.46^{*}$ & 17.80 & $20.18 *$ & 18.32 & $21.35^{*}$ \\
\hline & & $(1.88)$ & $(1.53)$ & $(1.71)$ & $(1.58)$ & $(1.81)$ \\
\hline \multirow[t]{2}{*}{$\mathrm{b}_{17}$} & Geographic distance & $-0.00 *$ & -0.00 & -0.00 & -0.00 & $-0.00 *$ \\
\hline & & $(-1.75)$ & $(-1.41)$ & $(-1.59)$ & $(-1.46)$ & $(-1.69)$ \\
\hline \multirow[t]{2}{*}{$\mathrm{b}_{18}$} & Economic distance & -0.05 & -0.05 & -0.05 & -0.05 & -0.06 \\
\hline & & $(-0.91)$ & $(-0.81)$ & $(-0.85)$ & $(-0.86)$ & $(-0.94)$ \\
\hline \multirow[t]{2}{*}{$\mathrm{b}_{19}$} & Host country’s GDP & $0.99 *$ & 0.77 & 0.87 & 0.80 & $0.92 *$ \\
\hline & & $(1.89)$ & $(1.43)$ & $(1.60)$ & $(1.49)$ & $(1.69)$ \\
\hline \multirow{2}{*}{$\mathrm{b}_{20}$} & Host country's GDP growth & $0.03 * *$ & $0.04 * *$ & $0.03 * *$ & $0.04 * * *$ & $0.04 * * *$ \\
\hline & & $(2.33)$ & $(2.55)$ & $(2.49)$ & $(2.58)$ & $(2.61)$ \\
\hline \multirow{2}{*}{$\mathrm{b}_{21}$} & Host country’s FDI inward & 0.00 & 0.00 & 0.00 & 0.00 & 0.00 \\
\hline & & $(0.31)$ & $(0.24)$ & $(0.27)$ & $(0.23)$ & $(0.26)$ \\
\hline \multirow[t]{2}{*}{$b_{22}$} & Host country's trade openness & -0.01 & -0.01 & $-0.01 *$ & -0.01 & $-0.01 *$ \\
\hline & & $(-1.49)$ & $(-1.52)$ & $(-1.76)$ & $(-1.49)$ & $(-1.70)$ \\
\hline \multirow[t]{9}{*}{$b_{23}$} & Host country's market reforms initiated & $0.59 * *$ & $0.59 * *$ & $0.57 * *$ & $0.58 * *$ & $0.56 * *$ \\
\hline & & $(2.44)$ & $(2.42)$ & $(2.33)$ & $(2.40)$ & $(2.29)$ \\
\hline & Constant & -3.95 & -3.91 & -3.58 & -4.97 & -3.15 \\
\hline & & $(-0.41)$ & $(-0.40)$ & $(-0.37)$ & $(-0.51)$ & $(-0.32)$ \\
\hline & Difference in coefficients Ho: $b_{1 G C \& G}-b_{1 \text { other firms }}=0$ & & $1.36^{*}$ & & & \\
\hline & $\mathrm{t}$ value of difference & & $(1.71)$ & & & \\
\hline & Observations & 20,736 & 20,736 & 20,736 & 20,736 & 20,736 \\
\hline & Number of firms & 18 & 18 & 18 & 18 & 18 \\
\hline & Log likelihood & -2286.62 & -2285.10 & -2282.37 & -2284.33 & -2272.56 \\
\hline
\end{tabular}


Figure 2. Governmental discretion effect on a RPIF's propensity to enter a foreign country, at different levels of infrastructure voids and investing in a country with the civil-code legal family

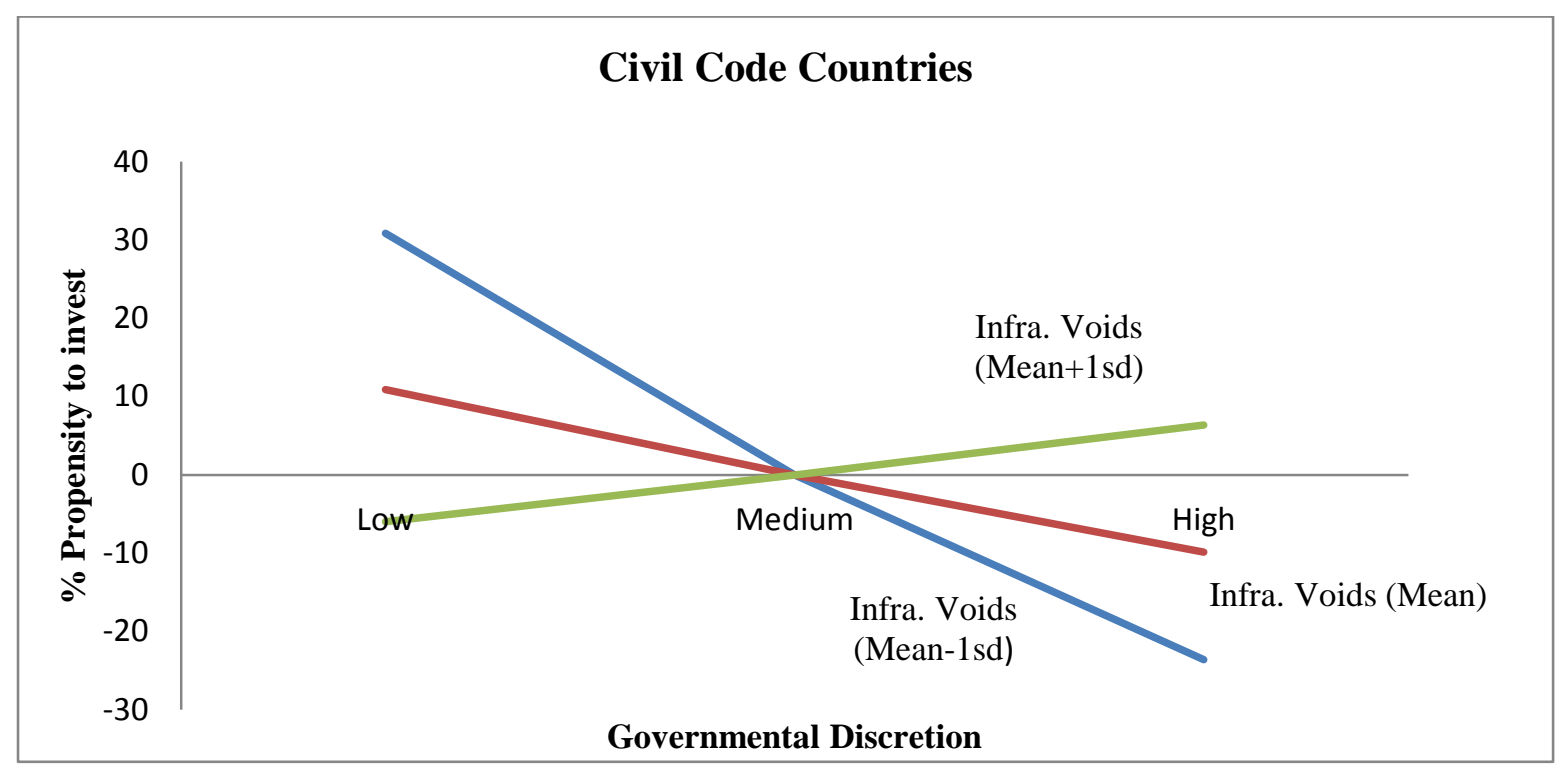


Figure 3. Governmental discretion effect on a RPIF's propensity to enter a foreign country, at different levels of infrastructure voids and investing in a country with a non-civil code legal family

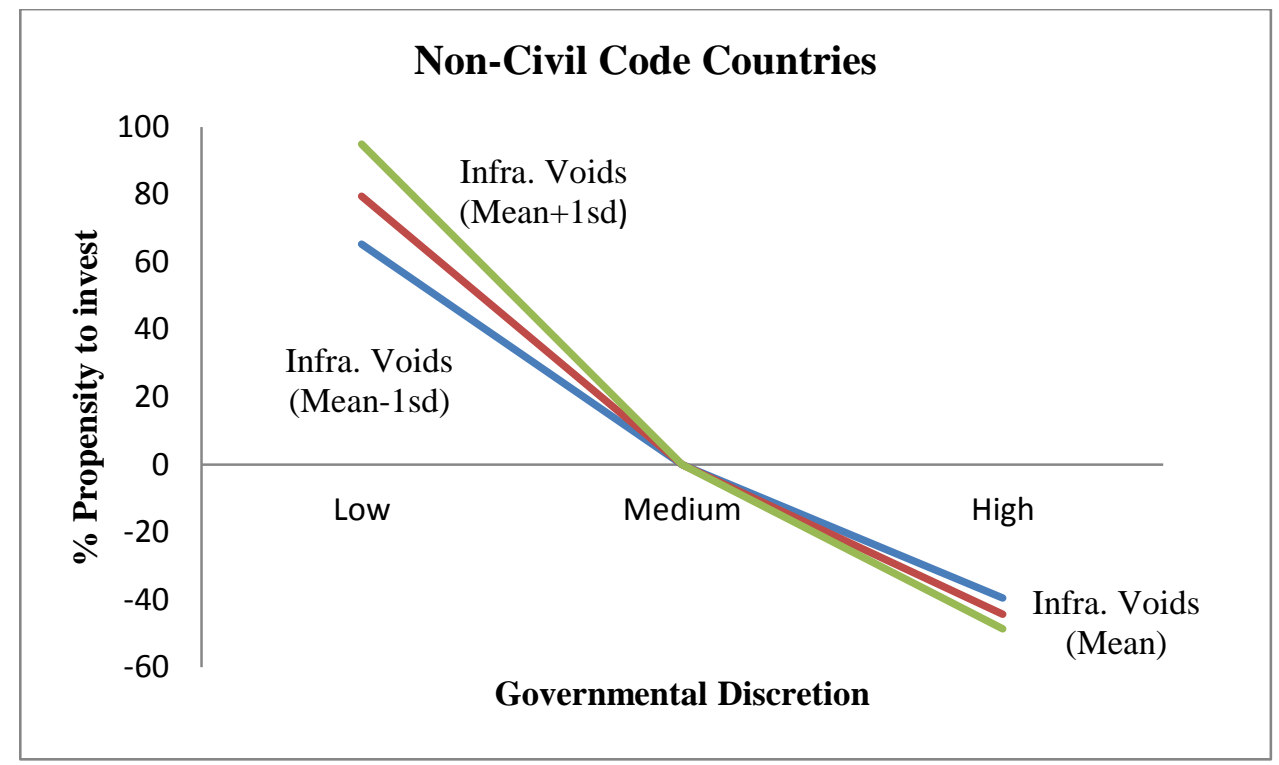




\section{References}

Alcantara, L.L., Mitsuhashi, H., 2012. Make-or-break decisions in choosing foreign direct investment locations. Journal of International Management 18(4), 335-351.

Allison, P.D., Waterman, R., 2002. Fixed-effects negative binomial regression models. Sociological Methodology 32(1), 247-265.

Amit, R., Schoemaker, P. J., 1993. Strategic assets and organizational rent. Strategic Management Journal 14(1), 33-46.

Bel, G., Fageda, X., 2013. Market power, competition and post-privatization regulation: Evidence from changes in regulation of European airports. Journal of Economic Policy Reform 16(2), 123-141.

Berry, H. 2006. Shareholder valuation of foreign investment and expansion. Strategic Management Journal 27(2), 1123-1140.

Berry, H. 2013. When Do Firms Divest Foreign Operations?. Organization Science 24(1), 246-261.

Berry, H., Guillén, M. F., Zhou, N., 2010. An institutional approach to cross-national distance. Journal of International Business Studies 41(9), 1460-1480.

Boddewyn, J.J., Brewer, T.L., 1994. International business political behavior: new theoretical directions. Academy of Management Review 19(1), 119-143.

Bonardi, J.P., 2004. Global and political strategies in deregulated industries: The asymmetric behaviors of former monopolies. Strategic Management Journal 25(2), 101-120.

Bonardi, J.P., 2011. Corporate political resources and the resource-based view of the firm. Strategic Organization 9(3), 247-255. 
Boubakri, N., Cosset, J.C., Guedhami, O., 2005. Liberalization, corporate governance and the performance of privatized firms in developing countries. Journal of Corporate Finance 11(5), 767-790.

Botero, J.C., Djankov, S., La Porta, R., Lopez-de-Silanes, F., Shleifer, A. 2004., The regulation of labor. The Quarterly Journal of Economics 119(4), 1339-1382.

Buckley, P., Clegg, J., Cross, A., Liu, X., Voss, H., Zheng, P., 2007. The determinants of Chinese outward foreign direct investment. Journal of International Business Studies 38: 499-518.

Cameron, A.C., Trivedi, PK., 1998. Regression analysis of count data. Cambridge: Cambridge University Press.

Campa, J.M., 1993. Entry by foreign firms in the United States under exchange rate uncertainty. The Review of Economics and Statistics, 75: 614-622.

Chua, C.L., Kim, D., Suardi, S., 2011. Are empirical measures of macroeconomic uncertainty alike? Journal of Economic Surveys 25(4), 801-827.

Chung, K.H., Pruitt, S.W., 1994. A simple approximation of Tobin's q. Financial Management 23: 70-74.

Cuervo-Cazurra, A., Genc, M., 2008. Transforming disadvantages into advantages: developing-country MNEs in the least developed countries. Journal of International Business Studies, 39: 957-979.

Cuervo-Cazurra, A., Genc, M., 2011. Obligating, pressuring, and supporting dimensions of the environment and the non-market advantages of developing-country multinational companies. Journal of Management Studies 48(2), 441-455.

Delios, A., Henisz, W.J. 2003. Political hazards, experience and sequential entry strategies: the international expansion of Japanese firms, 1980-1998. Strategic Management Journal 24(11), 1153-1164. 
Dorigoni, S., Portatadino, S., 2009. Natural gas distribution in Italy: When competition does not help the market. Utilities policy 17(3), 245-257.

Dowling, J., Pfeffer, J., 1975. Organizational legitimacy: Social values and organizational behavior. Pacific Sociological Review 18(1), 122-136.

Duanmu, J.L., 2012. Firm heterogeneity and location choice of Chinese multinational enterprises (MNEs). Journal of World Business 47(1), 64-72.

Dunning, J.H., 1993. Governments and Multinational Enterprises: From confrontation to cooperation? In L. Eden L., and E. Potter (Eds.), Multinationals in the Global Political Economy: 59-83. London: MacMillan.

Ethiraj, S. K., Kale, P., Krishnan, M. S., Singh, J. V., 2005. Where do capabilities come from and how do they matter? A study in the software services industry. Strategic Management Journal 26(1), 25-45.

Fainshmidt, S., White III, G. O., Cangioni, C., 2014. Legal Distance, Cognitive Distance, and Conflict Resolution in International Business Intellectual Property Disputes. Journal of International Management 20(2), 188-200.

Flores, R. G., Aguilera, R. V., 2007. Globalization and location choice: an analysis of US multinational firms in 1980 and 2000. Journal of International Business Studies 38(7), 1187-1210.

Frynas, J. G., Mellahi, K., Pigman, G. A., 2006. First mover advantages in international business and firm-specific political resources. Strategic Management Journal 27(4), 321-345.

Fuentelsaz, L., Garrido, E., Maicas, J. P., 2014. Incumbents, Technological Change And Institutions: How The Value Of Complementary Resources Varies Across Markets. Strategic Management Journal DOI: 10.1002/smj.2319

García-Canal, E., Guillén, M. F., 2008. Risk and the strategy of foreign location choice. Strategic Management Journal 29(10), 1097-1115. 
Glaeser, E., Shleifer, A., 2002. Legal origins. Quarterly Journal of Economics 117: $1193 \neg 1230$.

Grimsey, D., Lewis, M., 2007. Public Private Partnerships: The Worldwide Revolution in Infrastructure Provision and Project Finance. Edward Elgar

Guillén, M.F., 2005. The rise of Spanish multinationals: European business in the global economy. New York: Cambridge University Press.

Guillén, M.F., García-Canal, E., 2007. La expansión internacional de la empresa española una nueva base de datos sistemática. Información Comercial Española, ICE: Revista de Economía 839: 23-34.

Guillén, M.F., García-Canal, E., 2013. Emerging markets rule: Growth strategies of the new global giants. New York: McGraw-Hill.

Guler, I., Guillén, M.F., 2010. Institutions and the internationalization of US venture capital firms. Journal of International Business Studies 41(2), 185-205.

Guthrie, G., 2006. Regulating infrastructure: The impact on risk and investment. Journal of Economic Literature 44(4), 925-972.

Hausman J.A., Hall, B.H., Griliches, Z., 1984. Econometric models for count data with an application to the patents-RandD relationship. Econometrica 52: 909-938.

Henisz, W.J., 2000. The institutional environment for economic growth. Economics and Politics 12: 1-31.

Henisz, W.J., 2002. The institutional environment for infrastructure investment. Industrial and corporate change 11(2), 355-389.

Henisz, W.J., 2003. The power of the Buckley and Casson thesis: The ability to manage institutional idiosyncrasies. Journal of International Business Studies 34: 173-184.

Henisz, W.J., 2004. Political Institutions and policy volatility. Economics and Policy 16(1), $1-27$. 
Henisz, W.J., Delios, A., 2001. Uncertainty, imitation, and plant location: Japanese multinational corporations, 1990-1996. Administrative Science Quarterly 46(3), 443-475.

Henisz, W.J., Macher, J., 2004. Firm- and country-level trade-offs and contingencies in the evaluation of foreign investment: The semiconductor industry, 1994-2002. Organization Science 15(5), 537-554.

Henisz, W.J., Williamsom, O.E., 1999. Comparative economics organization - within and between countries. Business and Politics 1(3), 261-277.

Henisz, W.J., Zelner, B., 2001. The institutional environment for telecommunications investment. Journal of Economics \& Management Strategy 10(1), 123-147.

Henisz, W.J. Zelner, B., 2012. Strategy and competition in the market and non-market arena. Academy of Management Perspectives August (7)

Henisz, W.J., Zelner, B., Guillén, M.F., 2005. The worldwide diffusion of market-oriented infrastructure reform, 1977-1999. American Sociological Review 70(6), 871-897.

Hennart, J.F., 2009. Down with MNE-centric theories! Market entry and expansion as the bundling of MNE and local assets. Journal of International Business Studies 40(9), $1432-1454$.

Hillman, A. J., 2005. Politicians on the board of directors: do connections affect the bottom line?. Journal of Management 31(3), 464-481.

Holburn, G.L.F., Vanden Bergh, R.G., 2002. Policy and process: a game-theoretic framework for the design of non-market strategy. Advances in Strategic Management 19: 33ᄀ66.

Holburn, G.L.F., Zelner, B.A., 2010. Political capabilities, policy risk, and international investment strategy: Evidence from the global electric power generation industry. Strategic Management Journal 3: 1290-1315. 
International Country Risk Guide (ICRG). 2014. Methodology. http://www.prsgroup.com/wp-content/uploads/2012/11/icrgmethodology.pdf

Jaccard J., Turrisi, R., 2003. Interaction effects in multiple regression. Thousand Oaks, CA: Sage.

Jiang, G.F., Holburn, G.L.F., Beamish, P.W., 2014. The impact of vicarious experience on foreign location strategy. Journal of International Management 20(3), 345-358.

Jiménez, A., 2010. Does political risk affect the scope of the expansion abroad? Evidence from Spanish MNEs. International Business Review 19(6), 619-633.

Jiménez, A., Luis-Rico, I., Benito-Osorio, D., 2014. The influence of political risk on the scope of internationalization of regulated companies: Insights from a Spanish sample. Journal of World Business 49(3), 301-311.

Keim, G. D., Hillman, A. J., 2008. Political environments and business strategy: Implications for managers. Business Horizons 51(1), 47-53.

Kirkpatrick, C., Parker, D., Zhang, Y., 2006. Foreign direct investment in infrastructure in developing countries: does regulation make a difference? Transnational Corporations 15(1), 143-171.

Knickerbocker, F., 1973. Oligopolistic reaction and multinational enterprise. Boston: Division of research, Harvard Business School.

Kothari, T., Kotabe, M., Murphy, P., 2013. Rules of the Game for Emerging Market Multinational Companies from China and India. Journal of International Management 19(3), 276-299.

La Porta, R., Lopez-de-Silanes, F., Shleifer, A., 2008. The economic consequences of legal origins. Journal of Economic Literature 46(2), 285-332.

La Porta, Lopez-de-Silanes, F., Shleifer, A., Vishny, R., 1999. The quality of government. Journal of Law, Economics and Organization 15(1), 222-279. 
Lawton, T., Rajwani, T., 2011. Designing lobbying capabilities: managerial choices in unpredictable environments. European Business Review 23(2), 167-189.

Lawton, T., Rajwani, T., Doh, J., 2013. The antecedents of political capabilities: A study of ownership, cross-border activity and organization at legacy airlines in a deregulatory context. International Business Review 22(1), 228-242.

Lora, E., 2000. What makes reforms likely? Timing and sequencing of structural reforms in Latin America. Working paper no424, Inter-American Development Bank Research Department: Washington, D.C.

Luo, Y., 2004. A coopetition perspective of MNC-host government relations. Journal of International Management 10: 431-451.

Luiz, J., Rupla, M., 2010. Foreign direct investment and the internationalization of South African mining companies into Africa. Working paper.

Macher, J. T., Mayo, J. W., 2014. Influencing public policymaking: Firm-, industry-, and country-level determinants. Strategic Management Journal DOI: 10.1002/smj.2326

Madhok, A., 1997. Cost, value and foreign market entry mode: The transaction and the firm. Strategic management journal 18(1), 39-61.

Mahon, J. F., Murray, E. A., 1981. Strategic planning for regulated companies. Strategic Management Journal 2(3), 251-262.

Oliver, C., Holzinger, I., 2008. The effectiveness of strategic political management: A dynamic capabilities framework. Academy of Management Review 33(2), 496-520.

Parker, D., 2003. Performance, risk and strategy in privatised, regulated industries: The UK's experience. International Journal of Public Sector Management 16(1), 75-100.

Parker, D., Kirkpatrick, C. 2005. Privatisation in developing countries: A review of the evidence and the policy lessons. The Journal of Development Studies 41(4), 513541. 
Perkins, S. E., 2014. When Does Prior Experience Pay? Institutional Experience and the Multinational Corporation. Administrative Science Quarterly 59(1), 145-181.

Ramamurti, R., Doh, J. P. 2004. Rethinking foreign infrastructure investment in developing countries. Journal of World Business 39(2), 151-167.

Scott, R., 2011. The institutional environment of global projects. In R. Scott, R. Levitt, and R. Orr (Eds), Global projects: institutional and political changes: 52-85. New York: Cambridge University Press.

Servén, L., 1998. Macroeconomic uncertainty and private investment in developing countries: an empirical investigation. Policy research working paper no. 2035. The World Bank: Washington, D.C.

Teece, D. J., Pisano, G., Shuen, A., 1997. Dynamic capabilities and strategic management. Strategic Management Journal 18: 509-533.

U.S. Bureau of Economic Analysis. 2004., U.S. Direct Investment Abroad. Final Results from the 1999 Benchmark Survey. Government Printing Office:Washington, D.C.

Vergés J., 1999. Balance de las políticas de privatización de empresas públicas en España (1985-1999). Economía Industrial 330: 121-139.

Vergés, J., 2010. Privatización de empresas públicas y liberalización. Working Paper.

Wallsten, S., 2002. Does sequencing matter? Regulation and privatization in telecommunications reforms. World Bank Working Paper.

Zelner, B. A., Henisz, W. J., Holburn, G. L., 2009. Contentious implementation and retrenchment in neoliberal policy reform: The global electric power industry, 19892001. Administrative Science Quarterly 54(3), 379-412. 